\author{
Salar Salah Muhy Al-Din ${ }^{1}$ \\ Duško Kuzović \\ Maryam Iranfar ${ }^{3}$
}

JEL: Q2, P28

DOI: $10.5937 /$ industrija45-12770

UDC:

Original Scientific Paper

\title{
Renewable Energy Strategies to Overcome Power Shortage in Kurdistan Region of Iraq
}

\author{
Article history: \\ Received: 21 December 2016 \\ Sent for revision: 22 January 2017 \\ Received in revised form: 16 February 2017 \\ Accepted: 28 April 2017 \\ Available online: 1 July 2017
}

\begin{abstract}
The aim of this paper is to investigate the possibility of applying renewable energy strategies in Kurdistan Region of Iraq to overcome the shortage of electricity supply. Finding alternative renewable sources could overcome the problem. The renewable energy will reduce CO2 emission in the cities which considers the main source of pollution. That will participate in reducing the effect of global warming. The study tries to investigate the direct solar renewable energy through two of the main renewable energy categories to produce electricity based on a survey of literature review. Photovoltaic and wind power technologies are possible to be conducted in the region to overcome power shortage.
\end{abstract}

Keywords: Renewable Energy, Solar Radiation, Kurdistan Region of Iraq

\section{Strategija obnovljivih izvora energije radi prevazilaženja nedostatka energije u regionu Kurdistan Iraka}

Apstrakt: Cilj rada je istraživanje mougućnosti primene strategije za obnovljive izvore energije u regionu Kurdistan u Iraku radi prevazilaženja nestašice energije. Nalaženje alternativnih obnovljivih izvora može pomoći rešavanju problema. Obnovljivi izvori energije redukuju CO2 emisiju u gradovima koji se smatraju glavnim izvorima zagađenja. Takođe, strategija bi pomola smanjenju glabalnog zagrevanja. Studija istražuje efekte korišćenja direktne solarne energije. Obnovljivi izvori energije su moguća rešenja za prevazilaženje nestašice energije u ovom regionu.

\footnotetext{
${ }^{1}$ Girne American University- N. Cyprus, Faculty of Architecture, Design and Fine Arts

${ }^{2}$ Eastern Mediterranean University- N.Cyprus, Faculty of Architecture,

dusko.kuzovic@gmail.com

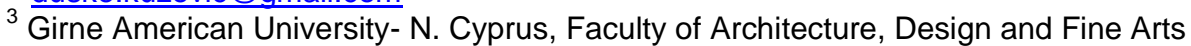


Al-Din S. et al.: Renewable Energy Strategies to Overcome Power Shortage in...

Ključne reči: obnovljivi izvori energije, solarna radijacija, region Kurdistan $u$ Iraku.

\section{Introduction}

The renewable energy became the main source in producing electricity in many developed and developing countries. Its usage is increasing and recently a large amount of investment has been made to enable the countries to produce renewable energy more cost effectively. There are eighteen countries that produce more than half of their electric power needs from renewable energy. Norway, Iceland New Zealand, Canada, and Brazil are among those countries (Meisen and Garzke, 2008). Renewable energy can provide our planet by low carbon emission power and cost effective energy Economic progress and countries development related with the demand for energy. In the last few years, energy demands have increased. Despite the area of Kurdistan is rich in oil, it has experienced energy shortages from the beginning of oil explore in the region until today.

Kurdistan Region of Iraq faces power blackouts reaches more than half of the day in some seasons because the shortage in producing enough electricity. The economic crisis and political conflicts between Kurdistan and the central government in Baghdad magnified the problem. That made the investments in power sector which mainly depended on producing power through none conventional resources came to an abrupt halt in 2014. The paper assign questions of; 1) how much renewable energy could be a remedy in solving the problems of Kurdistan in energy shortage. 2) Which technology of renewable energy is effective to solve power shortage problem? The aim of the study is the possibility of applying renewable energy strategies in Kurdistan Region of Iraq in order to overcome the shortage of electricity supply.

The paper tries to identify the potential of Kurdistan region to use the renewable energy to overcome the shortage of energy which it faces a long time back. The study attempts to evaluate the use of renewable energy in Kurdistan region as an alternative to fossil fuel based on its geographical location and its climate. The paper hypothesizes that if the renewable energy applied as alternative or co- source to produce energy, then KRG (Kurdistan region government) can improve the power condition in Kurdistan region. Until now we have no papers investigationg this topic. 
Al-Din S. et al.: Renewable Energy Strategies to Overcome Power Shortage in...

\section{Renewable Energy}

"Renewable energy" is the energy that flows through the environment in a natural way. There are many sources of these energy flows such as solar radiation incident on the earth's surface. Direct solar radiation is naturally the main cause for a number of other energy flows as; wind energy results from thermal inclination or variation across the earth's surface due to radiation incidence; wave energy results from the effects of winds on the oceans; and biomass energy, which is the chemical energy concealed in living organisms like a plants produces through photosynthesis process.

Part of Solar radiation also is converted to latent heat which results in potential energy embedded in the hydrological cycle. There are many other sources of energy flows apart of solar radiation and related to the gravitational force between earth and the moon, which known by tidal power. Geothermal energy comes from the heat of the earth core. The paper will focus on two types of these renewable energy sources which are solar power and wind power as strategies to be applied, because of their obvious presence in Kurdistan region climate.

\subsection{Solar Power}

Solar energy is the most obtainable permanent energy resource on earth and it has two forms; direct (solar radiation) and indirect (wind, biomass, hydro, ocean etc.). This paper will be limited to the direct use of solar radiation and focus on Solar Photovoltaic (PV) technology to produce the energy. The direct solar resource is massive. Solar radiation is absorbed on earth at an average rate of 120,000 TW ( $1 \mathrm{TW}=1$ terawatt $=1 \times 1012$ watts) (Lewis, 2007, P.816). However, this resource reaches the earth relatively as diffuse flow because of very fine drops of rain and microscopic fog or mist (Georgescu-Roegen, 1975).

The solar photovoltaic system is technology to convert light of sun directly into electricity using the effect of photoelectric, which through that, light causes matter to emit electrons. Many researchers have been investigated the advantages of solar power for residential, commercial and industrial consumption last twenty years.

Japan and Germany were the pioneers to use large-scale electricity generation by solar photovoltaic (PV) in last decade of the twentieth century. Both countries were leaders in the production of solar power technologies. Recently, China has developed wide solar power capacity taking the benefit of the cheap labor and government subsidies, which led to decrease the cost of solar power generation. The advantages of Solar Photovoltaic technology 
Al-Din S. et al.: Renewable Energy Strategies to Overcome Power Shortage in...

environmentally and economically are obvious. Reduction of fossil fuel usages like Coal, Petrol, and Natural gas to generate a power, will reduce $\mathrm{CO} 2$ emission and reduce global warming effects.

Nowadays, the cost of power generation cost has been significantly reduced by using conventional solar PV technologies, because of the development, and increase in efficiency, of solar power technologies. For example in USA the cost of power reduced because of using PV panel to generate electricity. On the other hand, there are also disadvantages of solar technologies, through degradation of the lands, affecting the aesthetic value in the buildings using this technology, and chemical effects of their material, etc. (Abolhosseini, et al., 2014). The efficiency of (PV) panel system is between $15 \%$ and $20 \%$ commercially (Kazem, et al., 2014, p.735).

\subsection{Wind Power}

The wind is the world's fastest-growing electricity sources. Its energy is a gathered kinetic energy of all of the molecules. The flow of the wind against the wind blades creates a rotational movement which can be used either to generate electricity. The wind turbines, which are using for generating electricity, have two or three blades fixed on a horizontal axis, generating power according to the wind speed. In 1996, the power of wind capacity reached 6,000 MW. More than 3000MW of this capacity was in Europe and much of the remaining in USA. Germany jumped giant leaps in this field. In 1994, it had installed capacity around 632 MW. With the beginning of 1998, the installed capacity in Germany had reached 2,079 MW. Performance in this field continues to develop, and costs continue to fall. Researchers estimated that the global market for wind energy will be reaching $\$ 133$ billion by 2020 (Jackson, 2007).

\section{Kurdistan Region Of Iraq}

The Kurdistan Region is located South-West of Asia and North-East of Iraq. The region has borders with Turkey from the north, Syria from the west, Iran from the east, and rest part of Iraq from the south. It is consist of three governorates; Erbil (Hawler), the capital of the region, Sulaymani, the Cultural capital, and Duhok. The region located within the Federal Republic of Iraq according to Iraqi Constitution, Article 62. The area of the region is 42,812 $\mathrm{Km} 2$ without the disputed area like Kirkuk, Khanaqin, and Shangar. The total area with these disputed areas is around $73,618 \mathrm{~km} 2$, which represents almost $17 \%$ of the total area of the Republic of Iraq. Kurdistan region located between longitudes $42^{\circ} 25^{\prime} \mathrm{E}$, and $46^{\circ} 15^{\prime} \mathrm{E}$, and between latitudes $34^{\circ} 42^{\prime} \mathrm{N}$ and $37^{\circ} 22^{\prime} \mathrm{N}$. The area of the three governorates; Sulaymani, Erbil, and 
Al-Din S. et al.: Renewable Energy Strategies to Overcome Power Shortage in...

Duhok are 17,023 Km2, 15,074 Km2, and 11,715 Km2, respectively (Rashid, 2014).

\subsection{Power generation existing scenario in the Region}

The demands on power in Kurdistan region has been increased dramatically within last decade. A total power demand in the Region based on official data in 2004 was 829 MW (Megawatt). Whereas, increased to reach 3279 MW in 2012. Means the demands on the power increased approximately 4 times over less than a decade from 2004 until 2012 (Ali, et al., 2015). The production of power in Kurdistan region has been also increased during last decade. The region was producing $482 \mathrm{MW}$ in 2007, which was raised to 484 $\mathrm{MW}$ in 2008. Power production jumped to be almost double within one year and reach $809 \mathrm{MW}$ in 2009, thus $1047 \mathrm{MW}$ in 2010, $1435 \mathrm{MW}$ in 2011 and finally to 2700 MW in 2012, see figure '1', (Kurdish Globe, 2013).

The data shows that there is a shortage in power supply by 579 MW in 2012, which means almost $82 \%$ of the total power demands are provided by the government. The demands increased more nowadays, especially after the tremendous displacement of people from other parts of Iraq to the region, since 2014 because of the fights against ISIS. KRG (Kurdistan Region Government could supply electricity between 12 to 19 hour per day and this number changes to more or less according to the seasons and demands. The remaining hours will be provided through private generators.

Figure 1. The Production of Electricity in Kurdistan Region of Iraq

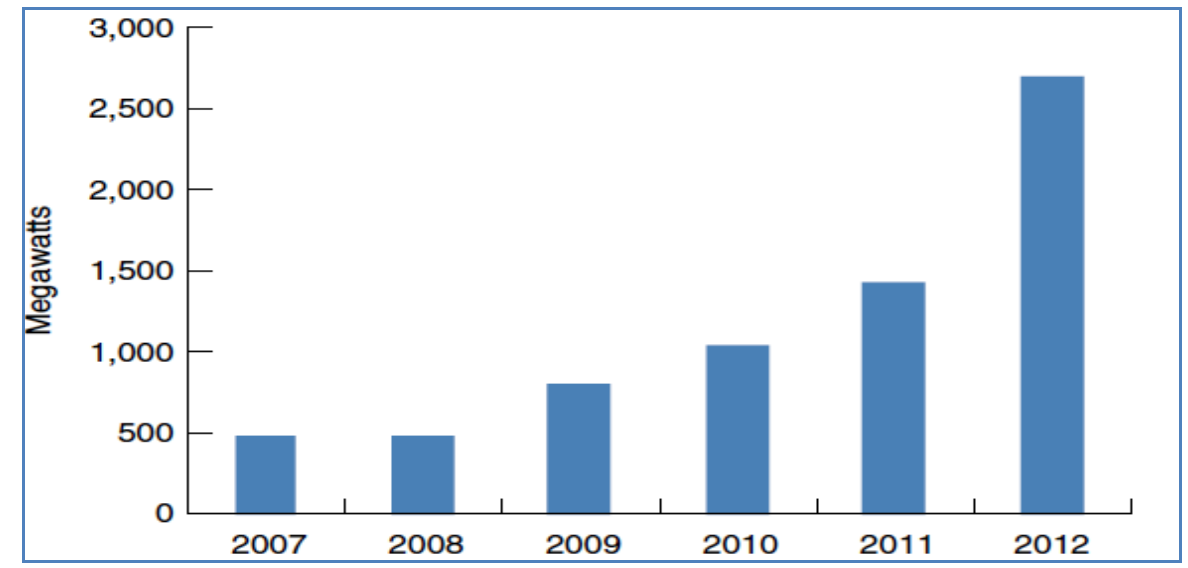

Source: (KRG, 2013) 
Al-Din S. et al.: Renewable Energy Strategies to Overcome Power Shortage in...

According to the ministry of Planning in Kurdistan region of Iraq, 5 Billion US\$ 'Five Billion American dollars' are required to overcome the shortage of the electricity in the region until 2020.

The power generation in Kurdistan region mainly depends on natural gas and hydropower generation from the dams of 'Darbandekhan' and 'Dukan' by design capacity of $650 \mathrm{MW}$ which sometimes reduced their capacity to $186 \mathrm{MW}$ and $146 \mathrm{MW}$ and in 2006, 2007, respectively (The Kurdistan region, 2009). The region receives electricity from adjacent countries like Iran and Turkey. But the region Government has their vision to explore the potential of using the renewable energy sources. According to the vision of government, renewable energy may be costly as the initial cost of building plants that use them, so the steps forward renewable energy generation technology should be careful to proceed. Although the advantages of this technology for our environment, but they also must evaluate financially (Ministry of PlanningKRG, 2013).

\subsection{Renewable energy in Kurdistan Region}

Kurdistan geographical position on earth globe gave it well situation regarding solar energy potential. The region located between $34^{\circ} 42^{\prime} \mathrm{N}$ and $37^{\circ} 22^{\prime} \mathrm{N}$ latitudes, which is highly abundant in solar energy irradiation region (Saeed and Qadir, 2010). Solar energy potential for the region can be evaluated by annual solar radiation as the average for Kurdistan region is $6318.83 \mathrm{MJ} / \mathrm{m} 2$ / year and equal to $1755.23 \mathrm{kWh} / \mathrm{m}^{2} /$ year, which is ' $4.81 \mathrm{kWh} / \mathrm{m}^{2} /$ day' (AbdulWahid, et al., 2010). Such average rate of the solar energy is encouraging for establishing a grid connected (PV) system to reduce the electricity shortage problems. Regarding wind source in Kurdistan region, the climatic data in the region indicate that in winter, Kurdistan influenced by Mediterranean cyclones which move east to northeast over the region. The Arabian Sea cyclones move northward passing over the Persian Gulf creating great humidity affecting Kurdistan region by recognizable amounts of precipitation. Occasionally, European winter cyclones move eastward to the southeast part of Turkey and over the mountainous region of Kurdistan, bringing substantial amounts of rain and snow. In summer, Kurdistan region influenced by Mediterranean anticyclones and subtropical high- pressure belts and center. The subtropical high- pressure centers that move from north to east and west to north above the Arabian Peninsula bringing dusty wind to the region. The daily temperature can drop to $-10^{\circ} \mathrm{C}$ in the cold season, and in the hot season the higher daily temperature could hit upper than 50。 C, (Saeed, 2012). These effects let the region face a big amount of the wind that gives the region the potential in using the wind to generate power. 
Al-Din S. et al.: Renewable Energy Strategies to Overcome Power Shortage in...

\section{Methods And Materials}

The methodology employed in this paper applied a qualitative study performed by a literature review on the several credible types of researches. The paper tried to select the studies which carried out about the renewable energy in different places inside Kurdistan region to get a more comprehensive understanding of the subject. The main aim of this research is to assess the potential of renewable energy to overcome power shortage in Kurdistan region. Evaluate the effect of involvement in the renewable energy on the region problems nowadays. The region faces a shortage in the power production, financial crisis, and environmental challenges. We will limit the study on direct solar system category, and focus on solar Photovoltaic (PV) and wind power technology through the literature and empirical tests in these two specific fields. Then we will extract indicators of the judgments about the usability of these two systems to solve the region problems through review the literature results. To reach proper findings, we quantify the outcomes in three directions; power generation availability, financial consideration, and environmental impact.

\subsection{Solar Photovoltaic technology potential in Kurdistan Region}

Recently, some researches and studies of solar energy and its aspects in the Kurdistan region of Iraq have been carried out. Data was obtained from Erbil city from solar radiation database "PVGIS-CMSAF". The results were demonstrating that the potential of Photovoltaic panel's technology to produce electricity are different according to the time within a day and the period within a year. (See table 1), (Azabany, et al., 2014).

The power output in Erbil area according to the table shows that the average rate of power output along the year is ' $0.79 \mathrm{kWh} / \mathrm{m} 2$ '. Another study has been carried out in 'Koya' city to investigate the potential of PV system to produce power for a $200 \mathrm{~kW}$ the results demonstrated that the total output is equal to ' $0.3 \mathrm{kWh} / \mathrm{m} 2$ ' and the total area covered by PV panels equal to 1400 square meter. Photo-Voltage Geographical Information System (PVGIS) software for this work has been simulated to evaluate the irradiation rate, optimal inclination, and assess the average obtained energy (Abdulrahman, et al., 2014). The system of PV panels to produce $200 \mathrm{~kW}$ costs with maintenance and operation US\$326,340 (Dr. Abdullah, 2014). A recent study in 'Sulaymani' investigated $\mathrm{CO} 2$ emission reduction through using Solar Photovoltaic (PV) project to supply $315 \mathrm{~kW}$ project. The study made a

${ }^{4} \mathrm{PV}$ GIS-(CM SAF) is an online tool to estimate the solar electricity production of a photovoltaic (PV) system, with (CM SAF) the Satellite Application Facility on Climate Monitoring database. 
Al-Din S. et al.: Renewable Energy Strategies to Overcome Power Shortage in...

comparison between the emission of $\mathrm{CO} 2$ from electricity produced by PV Panels and others which produced by fossil fuel. The study showed that the average values for the $\mathrm{CO} 2$ emissions for (PV) gives $0.105 \mathrm{~kg} \mathrm{CO} 2 / \mathrm{KWh}$ in time Coal gives $0.909 \mathrm{~kg} \mathrm{CO} 2 / \mathrm{kWh}$ (Khan, et al., 2014). These values can be considered to estimate and the reduction in $\mathrm{CO} 2$ emissions through using PV to produce electricity compared with other systems, which apply the fossil fuel to produce the electricity.

Table 1. The output of electricity for one square meter of PV Panels along the year in Erbil city.

\begin{tabular}{|l|l|c|}
\hline No. & \multicolumn{1}{|c|}{ Months } & Daily PV Output, $\mathrm{Wh} / \mathrm{m2}$ (15.1\% Efficiency) \\
\hline 1 & January & 557.19 \\
\hline 2 & February & 628.16 \\
\hline 3 & March & 773.12 \\
\hline 4 & April & 824.46 \\
\hline 5 & May & 915.06 \\
\hline 6 & June & 999.62 \\
\hline 7 & July & 984.52 \\
\hline 8 & August & 983.01 \\
\hline 9 & September & 954.32 \\
\hline 10 & October & 773.12 \\
\hline 11 & November & 620.61 \\
\hline 12 & December & 523.97 \\
\hline
\end{tabular}

Source: PVGIS-CMSAF

\subsection{Wind Power technology potential in Kurdistan Region}

Many studies have been carried out in the field of wind power generation in Kurdistan region. One of the studies selected several stations to be investigated and show the proper wind speed duration per year to produce power by mean of wind. The results have been shown that several of the places in Kurdistan region have a good wind potential. The highest speed of the wind founded in 'Chamchamal' area and it fluctuated between $13.66 \mathrm{~m} / \mathrm{s}$ (meter per second) in August and $6.50 \mathrm{~m} / \mathrm{s}$ in February. Also the average output power in this area per square meter registered more than $1 \mathrm{kWh} / \mathrm{m} 2$ for 9 months, (see table 2). The method that applied in this study was carrying out a simulation by the code HOMER, which is a computer model, developed by the National Renewable Energy Laboratory from the U.S. Department of Energy that helps to evaluate design options for both grid and off-gridconnected power systems (Husami, 2007). The study results are promising in the field of wind power in the region. 
Al-Din S. et al.: Renewable Energy Strategies to Overcome Power Shortage in...

Table 2. Monthly average wind speed and output power per m2 at 50m height in 'Chamchamal' station

\begin{tabular}{|c|c|c|}
\hline Month & Wind Speed m/s & Power (W/m2) \\
\hline Jan & 9.96 & 1229.1 \\
\hline Feb. & 6.5 & 340.8 \\
\hline Mar. & 10.19 & 1316.4 \\
\hline Apr. & 7.8 & 589.2 \\
\hline May & 11.49 & 1886.2 \\
\hline Jun. & 11.92 & 2106.6 \\
\hline Jul. & 12.99 & 2726.3 \\
\hline Aug. & 13.66 & 3166.1 \\
\hline Sept. & 10.83 & 1577.7 \\
\hline Oct. & 12.36 & 2346.3 \\
\hline Nov. & 11.26 & 1774.9 \\
\hline Dec. & 8.95 & 891.1 \\
\hline Avr. & 10.69 & 1580.2 \\
\hline
\end{tabular}

Source: (Husami, 2007)

One of other researches has been carried out in Kurdistan region to evaluate to identify any potential barriers to wind farm development and assess the capacity for large- scale wind projects. 'ArcGIS' 5 software has been applied for this purpose, in order to determine ultimate areas for wind projects based on several factors, such as; close to an electrical grid connection and availability of service roads to transport large turbines equipment. The research tried to suggest areas within $30 \mathrm{~km}$ of a $132 \mathrm{kV}$ substation or power stations. Several places have been identified and suggested for wind power development in Kurdistan region. The proposed places have been identified by two systems, the geographical coordinates system 'Longitude or Easting \& Latitude or Northing', and by global system 'UTM'6, (see table 3), (Esmael, et al., 2013).

\footnotetext{
5 'ArcGIS' Desktop is a GIS product developed by ESRI (Environmental Systems Research Institute) that allows analyzing a data and researcher's geographic knowledge to identify relationships, examine the predictions, and make better decisions.

${ }^{6}$ UTM (Universal Transfer Mercator's), the universal coordinate system to determine the locations on earth.
} 
Al-Din S. et al.: Renewable Energy Strategies to Overcome Power Shortage in...

'Garmyan' zone which located in the south of at Kurdistan region has been investigated for wind power generation. The places like (Kirkuk, Kalar, Khanaqin, and Touz Khormato) have been examined. The study has been chosen the level of 10 meter and 50 meters above the ground for this test. The annual wind energy densities were weak for (Kirkuk, Kalar, Khanaqin, and Touz Khormato) at the level of 10 meters, and 292.32, 696.87, 695.39, and $671.93 \mathrm{KW} /$ year/m2 at the level of $50 \mathrm{~m}$, respectively. The results showed that the wind powers in this zone are small for grid- connected power system purposes. Wind power can be applied only for agricultural application such as power generation for well water pumps until 100- meter depth using windmills, especially in the summer and spring because the higher wind speed recorded (Ibrahim and Saeed, 2010).

Table 3. Proposed Location for better wind power potential in Kurdistan Region

\begin{tabular}{|l|l|l|l|l|}
\hline Name & Longitude & Latitude & $\mathrm{X}($ UTM $)$ & $\mathrm{Y}(\mathrm{UTM})$ \\
\hline New Harir & 44.29052 & 36.60561 & 436548.0 & 40513557 \\
\hline Sikrin & 43.28234 & 37.03460 & 347232.6 & 4100090 \\
\hline New Erbil & 44.08497 & 36.20425 & 417742.8 & 4006991 \\
\hline Khabat & 43.70143 & 36.31144 & 383421.9 & 4019275 \\
\hline West Erbil & 43.94940 & 36.16185 & 405504.2 & 4002411 \\
\hline Perzen & 44.01420 & 36.24993 & 411431.8 & 4012121 \\
\hline South Erbil & 43.99710 & 36.12471 & 409752.1 & 3998246 \\
\hline Faeda & 42.91850 & 36.80920 & 314323.0 & 4075728 \\
\hline Sangasar & 45.03008 & 36.24100 & 502703.0 & 4010680 \\
\hline Bazian & 45.02074 & 35.67543 & 501877.0 & 3947950 \\
\hline
\end{tabular}

Source: (Esmael, et al., 2013).

The average size of grid-connected wind turbines is around 1.16 MW and between 2 to $3 \mathrm{MW}$ in new projects and even larger are available, as 'REPower's' $5 \mathrm{MW}$ wind turbine. To group wind turbines together, they are referred to as "wind farms". Wind farms consist of the turbines themselves, plus roads for site access, buildings, and the grid- connection point. Typically onshore wind farms range between USD 1 800/kW and USD 2 200/kW in major markets. However, wind farms were cost as low as USD 1300 to USD $1400 / \mathrm{kW}$ in China and Denmark, (International Renewable Energy Agency, 2012). Environmentally and according to IEA's (International Energy Agency) they estimates the emission of $\mathrm{CO} 2$ by $0.015 \mathrm{~kg} / \mathrm{kWh}$ as an average value from wind generation, (Thomas and Harrison, 2015). 
Al-Din S. et al.: Renewable Energy Strategies to Overcome Power Shortage in...

\section{Discussion And Findings}

According to the literature review, the needs of power in Kurdistan region is $3279 \mathrm{MW}$, and the actual availability of power from several sources are $2700 \mathrm{MW}$. Hence, the shortage is around $579 \mathrm{MW}$, and this data dates back to the end of 2012, means today the actual needs are more than this number. But the paper will deal with this number as a credible published data, in the same time the solutions are flexible and applicable with the same rhythm for a bigger shortage in the future. Theoretical analysis of the recent studies about Photovoltaic Panels (PV) potential in Kurdistan region demonstrates that the potential of this system is applicable and promising in several areas inside the region. The average rate of power output along the year in some places recorded by ' $0.30 \mathrm{kWh} / \mathrm{m} 2$ ' and in even more in specific places, to reach ' 0.79 $\mathrm{kWh} / \mathrm{m} 2$ ' and the efficiency of the system is between $15-19 \%$. The cost of PV project to generate $200 \mathrm{~kW}$ of power estimated by 326,340 US $\$$, which means $1,631.7$ US $\$$ per $\mathrm{kW}$ as initial cost plus the maintenance. The studies demonstrated also that each one kW needs to cover 7square meter land. Hence, the total cost to overcome the shortage of electricity in the region by using PV panels will be around $944,754,300$ US $\$$, and the total lands need to be covered are 4,030,000 square meter which is almost 4.03 square Kilometer. The average values for the $\mathrm{CO} 2$ emissions for (PV) gives $0.105 \mathrm{~kg}$ $\mathrm{CO} 2 / \mathrm{KWh}$ in time Coal gives $0.909 \mathrm{~kg} \mathrm{CO} 2 / \mathrm{kWh}$ and natural gas gives. The paper will compare carbon dioxide emission per $1 \mathrm{kWh}$ of electricity generation by this system with the generated by natural gas, considering natural gas as the main source to generate electricity in Kurdistan region. Natural gas powered electricity generation has $\mathrm{CO} 2$ emission almost half that of coal $0.5 \mathrm{Kg} / \mathrm{kWh}$ (Parliamentary Office of Science and Technology, 2006). The carbon footprint of PV technology for electricity production is only $21 \%$ of the power footprint of natural gas to generate electricity, which indicates an advantage environmentally. (See table 4).

Table 4, shows the total cost and lands needed to overcome the shortage of power in Kurdistan by PV system, as well as CO2 emission by PV technology and fossil fuel (Natural Gas) to generate electricity.

\begin{tabular}{|c|c|c|c|c|c|c|c|c|}
\hline $\begin{array}{l}\text { Electricity } \\
\text { Shortage } \\
\text { by MW }\end{array}$ & $\begin{array}{c}\text { Cost of } \\
1 \mathrm{~kW} \text { by } \\
\text { PV } \\
\text { (US\$) }\end{array}$ & $\begin{array}{l}\text { Land to } \\
\text { cover PV } \\
\text { panels to } \\
\text { produce } \\
1 \mathrm{~kW} \text { of } \\
\text { electricity } \\
\left(\mathrm{m}^{2}\right)\end{array}$ & $\begin{array}{c}\text { CO2 } \\
\text { Emission } \\
\text { per kWh } \\
\text { from } \\
\text { Photovolta } \\
\text { ic system } \\
(\mathrm{kg})\end{array}$ & $\begin{array}{c}\text { CO2 } \\
\text { Emissio } \\
\text { n per } \\
\text { kWh } \\
\text { from } \\
\text { Natural } \\
\text { gas } \\
\text { (kg) }\end{array}$ & $\begin{array}{l}\text { Total cost } \\
\text { (US\$) }\end{array}$ & $\begin{array}{l}\text { Total } \\
\text { Land } \\
\text { (M2) }\end{array}$ & $\begin{array}{c}\text { Total } \\
\text { CO2 } \\
\text { by } \\
\text { Natural } \\
\text { gas } \\
(\mathrm{kg})\end{array}$ & $\begin{array}{c}\text { Total } \\
\text { CO2 } \\
\text { by PV } \\
(\mathrm{kg})\end{array}$ \\
\hline 579 & 1631.7 & 7 & 0.105 & 0.500 & $944,754,300$ & $4,053,000$ & 298,500 & 60,795 \\
\hline
\end{tabular}

Source: Author. 
Al-Din S. et al.: Renewable Energy Strategies to Overcome Power Shortage in...

The findings demonstrate that the average power output in some places in Kurdistan region recorded more than $1 \mathrm{kWh} / \mathrm{m} 2$ for 9 months, except December, February, and April. Many places in Kurdistan according to recent researches identified as optimum places for wind farm projects. Based on software analysis, their climatic potential and their accessibility to main roads and electrical national grid elucidated the potential of those places. Thus, the results are encouraging for grid connected system wind power technology to overcome the shortage of electricity in the region. The literature review determined that the south part of Kurdistan region in Iraq which calls 'Garmian' zone is not very stimulating. The findings illustrated that the climatic characteristic for the zone is not hopeful for the grid- connected power system. It could be useful only for small- scale power generation for agricultural purposes to supply power generation for wells water pumps with100 meter depth or some limited uses through windmills.

The studies encourage the 10 meter to 50 - meter height above the ground for better results. CO2 emission for $1 \mathrm{kWh} / \mathrm{m} 2$ power generation by this technology is between $0.012-0.015 \mathrm{Kg} / \mathrm{kWh}$. Hence, $2 \mathrm{MW}$ or $3 \mathrm{MW}$ power productions or even $5 \mathrm{MW}$ wind turbine can be implemented in Kurdistan region. The $2 \mathrm{MW}$ turbines will be suggested in this region, seeking easier and more practical solutions to avoid construction and technological obstacles. The initial (establishing) cost of $1 \mathrm{KW}$ wind turbine is between 1800 US $\$$ to 2200 US $\$$, according to the as reviewed in Literature. The study will suppose 2000US\$ per $1 \mathrm{KW}$ as average. Thus, the total cost to overcome the shortage of electricity in the region will be $1,158,000,000$ US $\$$. This cost includes establishing wind turbines farms, service roads, grid connections and site buildings. A number of the Turbines will be ' 290 ' wind turbines and carbon dioxide emission for electricity generation by wind power will be only $3 \%$ from $\mathrm{CO} 2$ emission of the electricity generation by using natural gas. (See table 5).

Table 5, shows the total cost to overcome the shortage of power in Kurdistan by Wind power system, as well as CO2 emission by wind power technology and fossil fuel (Natural Gas) to generate electricity.

\begin{tabular}{|c|c|c|c|c|c|c|c|}
\hline $\begin{array}{c}\text { Electricity } \\
\text { Shortage } \\
\text { by MW }\end{array}$ & $\begin{array}{c}\text { Cost of } \\
1 \mathrm{~kW} \text { by } \\
\text { Wind } \\
\text { Tubine } \\
\text { (US\$) }\end{array}$ & $\begin{array}{c}\text { Total } \\
\text { number } \\
\text { of } \\
\text { required } \\
\text { Turbine } \\
\mathrm{s}\end{array}$ & $\begin{array}{c}\text { CO2 } \\
\text { Emission } \\
\text { per kWh } \\
\text { from } \\
\text { Photovoltaic } \\
\text { system }(\mathrm{kg})\end{array}$ & $\begin{array}{c}\text { CO2 } \\
\text { Emission } \\
\text { per kWh } \\
\text { from } \\
\text { Natural } \\
\text { gas }(\mathrm{kg})\end{array}$ & $\begin{array}{c}\text { Total cost } \\
\text { (US\$) }\end{array}$ & $\begin{array}{c}\text { Total } \\
\text { CO2 by } \\
\text { Natural } \\
\text { gas } \\
(\mathrm{kg})\end{array}$ & $\begin{array}{c}\text { Total } \\
\text { CO2 } \\
\text { by } \\
\text { wind } \\
\text { turbin } \\
\text { e }(\mathrm{kg})\end{array}$ \\
\hline 579 & 2000 & 290 & 0.015 & 0.500 & $1,158,000,000$ & 298,500 & 8,685 \\
\hline
\end{tabular}

Source: Author 
Al-Din S. et al.: Renewable Energy Strategies to Overcome Power Shortage in...

According to the ministry of planning in Kurdistan region, the region needs $5,000,000,000$ US $\$$ to overcome the problem. The paper came out with the results that illustrate the initial cost to solve the problem through renewable energy costs $1,158,000,000$ US $\$$ which is almost $20 \%$ of expected budget. Renewable energy system gives $97 \%$ to $79 \%$ reduction in $\mathrm{CO} 2$ emission through using PV Panel's or Wind power technology alternatively, compared with using natural gas as the power to generate electricity. The significant reduction of carbon footprint improves global climate. Hence, the international financial support to such projects will be helpful to reduce the global warming. Mixing both of the systems will fortify the system in order to depend on more than one renewable resource to generate electricity.

\section{Conclusion}

Theoretical analyses for several studies and researches have been approached. The results showed that Kurdistan region has a good potential to apply renewable energy strategies to generate the electricity. The potential fluctuated from place to place according to the micro-climatic characteristic. Also, it changes based on the season and even within one day. The paper ends with that both renewable energy systems, photovoltaic and wind power technologies are possible to be conducted in the region to overcome power shortage. The initial cost is relatively high and approximately same for both systems, but it is almost one over five from the expected budget determined by Kurdistan region government to solve this problem.

These types of projects will be cheaper when the payback period for 20 to 25 years be calculated as supposed life for these projects. That indicates they are more economic than other types of solutions. Suggested renewable energy strategies to generate electricity will have a positive impact on the environment. Reduction in carbon footprint occurs by more than $93 \%$ in wind power technology and $79 \%$ for solar photovoltaic system compared with using natural gas as the power to generate electricity. Consequently, it will improve the global environment, which it is deserved to be supported by other countries financially. Involve both technologies to overcome the shortage of electricity in the region will be a more responsible decision in order to diversify the resources.

The study opens the door for researchers to conduct the potential of other renewable energy sources in Kurdistan region of Iraq, as an alternative or cooperative solution for power shortage. 
Al-Din S. et al.: Renewable Energy Strategies to Overcome Power Shortage in...

\section{References}

Abdulrahman, A., Abdullah, S., \& Danial, C. (2014). Minimizing Electricity Shortages in Koya City in Iraq using Photo Voltage Gird System Simulation. International Journal of Computer Science and Electronics Engineering (IJCSEE), 2(2), 8891.

Abdul-Wahid, S.N., Mahdy, A., \& Godu, H.A. (2010). Calculation and Applications of Net Solar Radiation in Iraq. Journal of Al-Qadisiyah for Pure Science, 15(1), 130 .

Abolhosseini, S., Heshmati, A., \& Altmann, J. (2014). A Review of Renewable Energy Supply and Energy Efficiency Technologies. IZA Discussion Paper, 8145, 1-35.

Ali, J.A., Abdulrahman, R.K., \& Zangana, M.H. (2015). The Production of Biodiesel from Animal Tallow to be used for Electric Generators: A Case Study. Energy and Power, 5(1), 17-23. doi:10.5923/j.ep.20150501.03

Azabany, A., Khan, K., \& Ahmed, W. (2014). Solar Photovoltaic Generation Potential and Plant Capacity in Northern Iraq. Asian Journal of Science and Technology, 5(7), 423-426.

Abdullah, S.M., \& Abdulrahman, A.A. (2014). Economical Environmental and Performance Analysis for a 200 KW Ground Mounted Photovoltaic System: Koya City.

Esmael, R.S., Kareem, S.W., \& Abdulrahman, I.K. (2013). Wind Energy Proposed In Kurdistan-Iraq. Journal of Engineering Research and Applications, 3(6), 15311537.

Georgescu-Roegen, N. (1975). Energy and Economic Myths. Southern Economic Journal, 41(3), 347-381. doi:10.2307/1056148

Husami, M.S. (2007). Energy Crisis in Kurdistan and the Impact of Renewable Energy. UK: University of Strathclyde. Master Thesis.

Ibrahim, A.R., \& Saeed, M.A. (2010). Wind Energy Potential in Garmyan Zone. Diyala Journal for pure Science, 6(2), 170-182.

-International Renewable Energy Agency. (2012). Renewable Energy Technologies: Cost Analysis Series. Volume 1.

Jackson, T. (2007). Renewable Energy Sources. Guildford, Surrey, United Kingdom: University of Surrey - Centre for Environmental Strategy (CES).

Kazem, A.A., Chaichan, M.T., \& Kazem, H.A. (2014). Dust effect on photovoltaic utilization in Iraq: Review article. Renewable and Sustainable Energy Reviews, 37, 734-749.

Khan, K., Azabany, A., \& Ahmed, W. (2014). Reductions in CO2 emissions from Electricity Generation from Solar Energy at Sulaymanyah Airport in Kurdistan, Iraq. Asian Journal of Science and Technology, 5(8), 479-481.

-Kurdish Globe. (2013). Power production to double in three years. Retrieved from http://www.kurdishglobe.net/article/FE3DD6CAFFBD9A640F9113FD6D379D06/ Power-production-to-double-in-three-years.html 2016 Aug 27.

Lewis, N.S. (2007). Powering the Planet. MRS Bulletin, 20(1), 808-820. [Retrieved] on 23rd of August, 2016, from file://C:/Users/Dell/Documents/Downloads/ptp-mrsbulletin-oct-2007\%20(1).pdf. 
Al-Din S. et al.: Renewable Energy Strategies to Overcome Power Shortage in...

-Ministry of Planning- Kurdistan Region Government. (2013). Kurdistan Region of Iraq 2020: A Vision for the Future. Retrieved from http://www.iraqjccme.jp/pdf/archives/krg_2020_english.pdf 2016 Aug 23.

-Parliamentary Office of Science and Technology. (2006). Postnote: Carbon Footprint of Electricity Generation. Retrieved from http://www.parliament.uk/documents/post/postpn268.pdf 2016 Sep 3.

Rashid, R.H.M. (2014). The Use of Water for Sustainable Rural Development: A Case Study in the Kurdistan Regional Government. Cluj-Napoca, Romania: University of Agricultural Sciences and Veterinary Medicine. Doctoral Thesis.

Saeed, M.A., \& Qadir, K.W. (2010). Study and Analysis of Global and Extraterresterial Solar Radiation over Kurdistan Region-Iraq. In: 3rd International Scientific Conference, Salahaddin University, Erbil. Kurdistan Region of Iraq. October.

Saeed, M.A. (2012). Analysis of Climate and Drought Conditions in the Federal region of Kurdistan. International Scientific Journal Environmental Science, 2, Retrieved from http://environment.scientific-journal.com

-The Kurdistan Region. (2009). Powering Up Kurdistan: Professor Brendan O'Leary interviews Hoshyar Siwaily, the Kurdistan Regional Government's Minister of Electricity. In Invest in the Future: An official publication of the Kurdistan regional Government. (pp. 102-107). Retrieved from http://cabinet.gov.krd/uploads/documents/invest_in_kurdistan_2009.pdf 2016 Aug 29. 